\title{
The Safety and Soundness Effects of Bank M\&A in the EU
}

\author{
Jens Hagendorff, Maria J. Nieto, and Larry D. Wall
}

\section{Working Paper 2012-13 \\ September 2012}

\begin{abstract}
This paper studies the impact of European bank mergers and acquisitions on changes in key safety and soundness measures of both acquirers and targets. We find that capitalization, profitability, and liquidity show signs of statistically and economically significant mean reversion for acquirers. Also, acquirers in cross-border deals tended to perform better when their home country prudential supervisors and deposit insurance funding systems were stricter than the target's. For target banks, the most consistent findings from the cross-sectional regressions are that stronger supervision and tougher deposit insurance funding regimes tend to result in positive postmerger changes in liquidity and performance.
\end{abstract}

JEL classification: G21, G34, G28

Key words: banks, mergers, Europe

The authors thank Ignacio Hernando, Leonidas Barbopoulos, and Allen Berger, Tobias Michalak, Arnie Cowan, Chen Liu, Kristina Minnick, Benton Gup and participants at the Southern Finance Association, Infiniti Conference on International Finance, and the Eastern Finance Association meetings. The views expressed here are the authors' and not necessarily those of the Federal Reserve Bank of Atlanta or the Federal Reserve System or the Banco de España. Any remaining errors are the authors' responsibility.

Please address questions regarding content to Jens Hagendorff, the University of Edinburgh, Business School, 29 Buccleuch Place, EH8 9JS, Edinburgh (United Kingdom), +44(0)131 6502796, jens.hagendorff@ed.ac.uk; Maria J. Nieto, Banco de España, Alcalá 48, 28014 Madrid (Spain), +34 9133862 86, maria.nieto@bde.es; or Larry D. Wall, Research Department, Federal Reserve Bank of Atlanta, 1000 Peachtree Street N.E. Atlanta, GA 30309-4470 (USA), +1 404-498-8937, larry.wall@atl.frb.org.

Federal Reserve Bank of Atlanta working papers, including revised versions, are available on the Atlanta Fed's website at frbatlanta.org/pubs/WP/. Use the WebScriber Service at frbatlanta.org to receive e-mail notifications about new papers. 


\section{The Safety and Soundness Effects of Bank M\&A in the EU}

\section{Introduction:}

This paper examines post-merger changes in the balance sheets and operating performance of acquiring and target banks in the European Union before the start of the global financial crisis with an emphasis on the implications for bank safety and soundness. The EU has a policy of encouraging cross-border mergers as a way of developing a single market for financial services with the adoption of the euro providing added emphasis on integrated financial markets in the eurozone. Bank mergers, both within country and across Member States in the EU, may come with an added benefit in the form of safer banks as weaker banks are taken over and financially strengthened. Additionally, bank mergers may result in stronger post-merger groups to the extent that the target imports the benefits from relatively stricter consolidated supervision. Alternatively, mergers could come with the cost of financially weaker acquirers and targets. Banks could become weaker and more dependent upon the safety net if they are able to reduce the effectiveness of regulation either by exploiting new opportunities for regulatory arbitrage between countries or by obtaining greater influence over the prudential supervisors in its home country - especially for purely domestic mergers (i.e. banks that could become "too-big-to-fail"). Further, unlike studies of post-merger changes in U.S. banks, we can provide some evidence on the effect of prudential supervision and deposit insurance. The problem with studies that focus exclusively on U.S. mergers is that those banks face a relatively homogenous set of prudential and deposit insurance regulations. In contrast banks in the EU can have substantially different regulatory and deposit insurance systems subject only to the minimum harmonization.

Our analysis focuses on three variables of interest to prudential supervisors: (1) capitalization as proxied by the equity capital to total assets ratio, (2) performance as proxied by 
return on assets (ROA), and (3) liquidity as proxied by the funding ratio (the ratio of liquid assets to the sum of customer deposits and short-term funding). Bank capitalization has long been the focus of prudential supervisors as banks with more capital have a greater solvency buffer for dealing with unfavorable shocks to asset values and have easier access to liquidity in the markets. Higher performance similarly creates a larger buffer providing greater ability to absorb adverse shocks to asset values and greater ability to rebound as conditions improve. Liquidity also provides a buffer from unfavorable shocks but in the form of time rather than loss absorption. If a bank absorbs an adverse shock with low liquidity buffers, it may come under considerable stress to obtain liquidity in the market in the short term, whereas banks with large liquidity buffers will have time to demonstrate their underlying solvency to the market. Moreover, even if a bank is insolvent after an adverse shock, the supervisors will likely have more time to respond to the insolvency if the bank is more liquid.

It should be highlighted that our empirical analysis explores post-merger changes both in the acquirer and the target from one year prior to two years after completion of a merger. This is, we attempt to fully isolate the short-term impact of mergers and acquisitions (M\&As) on variables of special interest to prudential supervisors taking into consideration the stringency of their prudential regulation and safety net support via deposit insurance. ${ }^{1}$

There is a substantial literature on bank mergers, with Berger, Demsetz and Strahan (1999) referencing 250 papers in their survey on bank consolidation and DeYoung, Evanoff and Molyneux (2009) referencing another 150 papers in their survey of the post-2000 literature. ${ }^{2}$

\footnotetext{
${ }^{1}$ Note that we use the terms regulation / supervision interchangeably for the purpose of this paper.

${ }^{2}$ See also Rhoades (1994), Amel, Barnes, Panetta and Salleo (2004), and Jones and Critchfield (2005) for surveys of the bank merger literature.
} 
Most of the studies referenced in these two papers focus on the large literature analyzing U.S. takeovers, but both papers also include some discussion of the smaller literature on bank consolidation in Europe. However, only a fraction of these studies overlap with the issues addressed in this paper and we are not aware of any recent study that examines the post-merger changes in the banks' financial ratios from a prudential supervisory perspective in the EU.

The remainder of the paper is organized as follows. The literature review is in the next section. The third section develops a multivariate model, while the fourth section reviews the data and provides univariate statistics. The fifth section presents our model results, while concluding remarks and policy implications are provided in the final section.

\section{Literature review}

The causes and consequences of bank takeovers have been analyzed in the literature from a variety of perspectives. The following brief overview focuses on the implications of different types of merger studies for post-merger changes in bank profitability, capital and liquidity.

The first step in the merger process is that of determining whether the bank is going to participate in a merger and, if so, whether as an acquirer or target. The part of the Berger, Demsetz and Strahan survey that addresses this issue focuses on the relative efficiency of the two parties before the takeover. Their summary suggests that more efficient acquirers tend to buy less efficient targets in the U.S. and Europe. More recently Hannon and Pilloff (2009) find that acquirers tend to purchase less profitable targets in the U.S. ${ }^{3}$ Most specifications in Hernando, Nieto and Wall's (2009) analysis of bank takeovers in Europe find a significant positive

\footnotetext{
${ }^{3}$ Hannon and Pilloff (2009) also find evidence that banks with lower capital to asset ratios are more likely to be acquired. However, this finding does not necessarily have any implications for post-merger changes in capital under their preferred explanation.
} 
coefficient on the cost to income ratio of the target but an insignificant coefficient on the return on average assets.

Along with the determination of which institutions are acquired, the literature has also examined the prices paid for bank acquisition targets. The issue addressed by this literature that is most relevant to this paper is whether the prices paid are consistent with acquirers seeking to reduce their exposure to supervisory discipline and possibly increase their risk profile. Benston, Hunter and Wall (1995) examine bank merger premiums paid and fail to find evidence that acquirers purchase more risky banks. Several recent studies suggest, however, that banks seek to reduce their regulatory burden. Brewer and Jagtiani (2007) find evidence that banking organizations will pay a premium to targets in order to grow above the thresholds associated with being 'too-big-to-fail'. Two recent studies of European mergers also find evidence of regulatory avoidance and acquirers seeking to become too-big-to-fail. Hagendorff, Hernando, Nieto and Wall (2011) find that the premiums paid in European mergers are significantly lower in countries with stricter regulatory and stronger deposit insurance regimes. However, when takeovers are separated into domestic and cross-border takeovers, the impact of regulatory and deposit insurance regimes is only significant for domestic mergers. By contrast, Carbo-Valverde et al. (2009) find that banks which had engaged in cross-border M\&A activity extract higher safety net subsidies and that these banks did not become more efficient. Their findings are consistent with the deposit insurance put hypothesis. Molyneux, Schaeck, and Zhou (2010) also find that listed bank merger premiums paid are positively correlated with the probability of banks becoming too-big-to-fail. A third type of evidence comes from studies of changes in shareholder wealth of publicly traded participants in bank takeovers. In terms of overall results, DeYoung, Evanoff, and Molyneux (2009) find a divergence between the studies in the 1980s and 1990s versus those 
in the 2000s. The earlier literature typically found that targets obtain positive abnormal returns, acquirers earned small negative returns and the combined returns were statistically insignificant or economically small. More recently, only European bank deals have increased shareholder value (Hagendorff, Collins and Keasey, 2008). Beitel, Schiereck and Wahrenburg (2004) find that for their sample of European takeovers the coefficient on the relative cost-to-assets ratio is significant for targets but not for bidder returns or combined returns. They fail to find a significant relationship between shareholder returns and pre-merger profitability. Campa and Hernado (2006) find that relatively smaller targets have higher announcement returns for a sample of bank and non-bank financial takeovers in Europe. Beccalli and Frantz (2009) show that bank M\&As cause a slight deterioration in return on equity, cash flow return and profit efficiency.

Some studies have also examined post-merger changes in the target or acquirer or both. Berger, Demsetz, and Strahan (1999) review studies of post-merger profitability (ROA and ROE) and the findings of studies using production functions for estimates of post-merger changes x-efficiency. The post-merger profitability studies tended to be split between improved profitability and no change in profitability. Their survey also concludes that the results of analyzing changes in cost $\mathrm{x}$-efficiency concur with simpler ratio-based cost studies that bank mergers produce little or nothing in terms of cost reductions - albeit there was some evidence of improvement if the participants were less efficient than their peers. Vander Vennet (2002) analyzes changes in cost and profit efficiency for a sample of European cross-border mergers. He finds evidence of an increase in profit efficiency but not in cost efficiency. ${ }^{4}$ Hagendorff and

\footnotetext{
${ }^{4}$ However, Vander Vennet (2002) also notes that there may be various short-run barriers to improving cost efficiency for European takeovers.
} 
Keasey (2009) find evidence of lower cost ratios post-merger in their sample of European banks with accompanying reductions in lending activity.

Another issue explored by the literature is the role of the extent of similarity (or relatedness) of the pre-merger target and the acquirer on various aspects of bank takeovers. Many studies incorporate one aspect of pre-merger similarity into the analysis, such as measures of relative size or efficiency. Surveys of this literature by Altunbaş and Marqués (2008) and DeYoung, Evanoff and Molyneux (2009) find that mergers that increased product line focus produced higher abnormal returns. Additionally, Altunbaş and Marqués (2008) provide new evidence that focusing mergers resulted in better performance for domestic takeovers but that the nature of the strategic aspect was important for cross-border mergers. For example, they find that differences in their premerger credit risk strategies were associated with higher performance whereas greater differences in cost structure were associated with lower performance.

Thus, the issues of post-merger changes in profitability and capital have been touched upon in the literature using a variety of different approaches. The evidence supporting the hypothesis that bank mergers lead to higher profitability post-merger is weak at best. There also is some evidence that bank mergers are used as a tool to become larger, perhaps with the goal of becoming too-big-to-fail. This study analyzes the immediate post-merger changes in three variables of special interest to supervisors (solvency, liquidity and profitability) while controlling for the stringency of national prudential regulatory frameworks as well as explicit safety net support in the form of deposit insurance.

The closest paper to this paper is Carbo-Valverde, Kane and Rodriguez-Fernandez (2012). The authors focus on changes in estimated fair values of deposit insurance for banks that do and do not engage in cross-border mergers. Their measure of deposit insurance value is a 
potentially more comprehensive measure of changes in risk but it relies on return volatility estimates that may increase for reasons that do not necessarily suggest the acquisition caused the acquirer to become more risky. The present paper adds to Carbo-Valverde et al. (2012) in a variety of ways.

First, based on our sample, often times the target is tiny relative to the acquirer suggesting that changes in the acquirer's strategy may be responsible for both the acquisition and the increase in the measured risk of the acquirer. Indeed, in our subsample of 41 cross-border takeovers, the median value of target assets is only 1.6 percent of acquirer assets. While CarboValverde et al. (2012) use a somewhat different time period and a different method of identifying mergers, the results from our sample suggest that a large fraction of the cross-border observations is likely to consist of large acquirers buying tiny targets. As an alternative that provides some information on the impact of larger acquirers buying small targets, we also include in our analysis those targets that retain separate bank charters.

Second, assuming the target is large enough to materially impact the acquirer's financial condition, both accounting and market measures of deposit insurance values are potentially vulnerable to the merger causing greater variability of returns for reasons that do not necessarily imply a higher risk of failure. Accounting measures of risk may capture post-merger write downs of asset values and possibly temporarily higher personal expense as the firms are integrated. Market measures of return volatility may reflect an increase in the news related to the combined bank's future operations, both news that suggests greater downside risk and greater upside potential. Unfortunately, as one expands the post-merger time period to avoid noise from their consolidation, one also begins to pick up other events unrelated to the merger. Thus, rather than focusing on risk estimates, this paper focuses more narrowly on returns. 
An additional difference between this paper and Carbo-Valverde et al. (2012) is in the analysis of regulatory arbitrage. Their paper conjectures that the differences are due to regulatory arbitrage across borders but does not include any measures of regulatory arbitrage potential. By contrast, our paper includes measures for both the acquirer and the target. Further, we not only have a measure of prudential regulatory strength but also deposit insurance funding practices as systems with ex ante, risk-based funding may reduce the extent to which the banks could benefit from regulatory arbitrage.

\section{Model}

To analyze the factors that determine changes in solvency, liquidity and profitability on acquirer and target banks in a multivariate setting, we estimate the following regression model.

Post-mrgr change $_{i, j}=\alpha+\beta_{1}$ control $_{j}+\beta_{2}$ relatedness $_{j}+\beta_{3}$ regulatory $_{j}+\varepsilon_{i, j}$,

where

$$
\begin{aligned}
& \text { Post-mrgr change }_{i, j}=\text { changes in } i \text { for bank } j \text { between years }-1 \text { to }+2 \text { relative to the } \\
& \text { merger completion year. Financial variables are measured } \\
& \text { separately for the target and for the acquirer. For targets, we } \\
& \text { compare unconsolidated bank data before and after a deal. For } \\
& \text { acquiring banks, we compare pre-merger values for the acquirer } \\
& \text { with post-merger data for the consolidated banking group. } \\
& \text { control }_{j} \quad=\text { vector of control variables for firm type } j \text {, } \\
& \text { relatedness }_{j} \quad=\text { vector of relatedness variables for firm type } j \text {, } \\
& \text { regulatory }_{j} \quad=\text { vector of regulatory variables for firm type } j \text {, } \\
& i \quad=\text { set of dependent variables which are capitalization (capasset } \\
& \text { which is the equity-to-assets ratio), performance }(R O A=\text { return on }
\end{aligned}
$$


assets), and liquidity (liquid $=$ liquid assets [trading assets and loans with less than three months to maturity] scaled by customer funding and funding with a maturity of less than three months. Merger-related changes between years -1 and +2 are denoted by the prefix $d$ (dcapasset, $\mathrm{d} R O A$, and diquid), $j=$ = firm type equal to target or acquirer, $\beta_{1}, \beta_{2}, \beta_{3} \quad=$ vectors of coefficient values, and $\varepsilon_{i, j} \quad=$ random heteroscedasticity-robust error

A reasonable assumption is that the acquirer made changes in the target after obtaining control rights. Thus, as a first approximation most of the coefficients in the target and acquirer equation are assumed to reflect the managerial decisions of the acquirer. ${ }^{5}$ The supervisory implication is that the observed changes in the target and acquirer's operations would not have happened if the merger had not occurred if the prudential supervisors would have not authorized the M\&A under the concern of the financial impact on the banking group. However, a common limitation of all studies of acquirer's post-merger performance is that there are three reasonable, not mutually exclusive, hypotheses. Merger-related changes in the acquirer may be due to: (1) the simple consolidation effect of adding the target's income and balance sheet values to the acquirer; (2) the effect of any managerial changes the acquirer made on the target, and (3) the acquirer's strategy which may dictate both changes in its own operations and the type of target acquired by the bank. The first two possibilities would suggest that the merger caused the observed change in the acquirer with the implication that the changes would not have happened if the supervisors had blocked the merger for some reason. The third hypothesis, however,

\footnotetext{
${ }^{5}$ We exclude failed banks so that saving failing banks' should not play an important role in our study.
} 
would suggest that the acquirer would likely have made the operational changes regardless of whether it acquired the target. We cannot distinguish among these three hypotheses in our empirical analysis.

The explanatory variables fall into three general categories: control variables, relatedness variables and variables directly related to regulatory concerns.

\subsection{Control variables}

If our dependent variables are subject to random shocks, part of their adjustment over our three-year window may merely be movement towards their mean value. If so, changes in the dependent variable over a given time period should be negatively related to their values in the first year ( $t$-1). For example, if earnings changes are measured from $t-1$ to $t+2$, these changes should be negatively related to the level of earnings in $t-1$ as the shocks return to their mean value of zero. Building on Fama and French (2000), Knapp, Gart and Chaudhry (2006) estimate models of changes in industry-adjusted ROA and ROE for banks and consistently find a significant negative coefficient on their base year value.

Bank managers may also make non-random changes in capital, liquidity and earnings that induce a negative correlation similar to that observed by Knapp, Gart and Chaudhry (2006). Prior to the merger, the participants may manage their premerger accounting earnings with a goal of improving their negotiating position in takeover talks. Also, the acquirer may temporarily boost its premerger capital and liquidity ratios in order to enhance its ability to obtain supervisory approval for the takeover. Non-random post-merger changes in target capital may occur to the extent that the target's supervisor required the acquirer to inject additional capital into the target as a condition for approving the takeover. Altunbas and Marqués (2004) also find a significant negative coefficient on the one-year lagged performance variable for a sample of 
EU bank mergers. Thus, each equation includes the level of the variable being analyzed as of $t$ -

1. For example, the equation estimating merger-related changes in capitalization (dcapasset), the target capital ratio at $t-1$ is included (lever $t-1)$. The coefficient on this variable is expected to have a negative sign. Coefficients between zero and -1 could merely be due to mean reversion in balance sheet items. However, coefficients with values less than -1 would be suggestive of deliberative effort by the banks to boost their reported premerger capital, liquidity and/or earnings.

A third control variable is toe which is a binary variable that takes the value of 1 if the acquirer owned shares in the target prior to the acquisition (that is, the acquirer already has a "toe hold"). If the acquirer already has an ownership interest in the target, it is possible that the target has already started to make some of the changes that would be desired by the acquirer. Thus, the expected sign on this variable is negative. Moreover, the impact of toe is likely to be more significant on the target's operations than on the consolidated results as prior ownership interest is likely to have little impact on the acquirer's operations pre-merger.

Another control variable is a measure of competition in the market proxied by an assetbased Herfindahl Hirschman Index $(H H I)$ of market concentration which we compute at country level (using all banks listed on Bankscope). The structure-conduct-performance paradigm holds that there is less competition and hence higher potential profits in more concentrated markets. The direct effect of the acquisition may be to further increase concentration and thereby increase profitability, especially in domestic takeovers. However, there are at least two hypotheses that suggest a negative correlation. First, it is also possible that the takeover will result in management changes that at least temporarily reduce the target's ability to exploit the benefits of market concentration. Second, the acquirer may seek temporarily faster growth on the part of 
targets in more concentrated markets which may also depress profitability. Thus, the implications for the coefficient on $R O A$ are ambiguous. Any changes in $R O A$ could feed through to retained earnings and capitalization, producing a positive or negative association between $H H I$ and capasset. HHI is also included in the liquid equation for completeness.

Finally, we include GDP growth during the year of the merger (gdpgrwth). Banks operating in faster growing economies may make larger adjustments than banks in slower growing economies. The expected sign on this variable is ambiguous. Banks in faster growing economies should have a higher net income in the future and possibly in the short run. Thus, it is possible that these banks will report higher levels of capasset due to higher retained earnings; higher $R O A$ due to more business opportunities, and lower liquid due to excess lending opportunities over typical retail funding sources. However, banks in faster growing markets may choose to forgo some current profits to invest in growth. The result could be that the banks would report lower changes in capasset and $R O A$ since profitability and retained earnings are being sacrificed in the short-run in favor of market share. In this case, we can expect higher liquid assets over typical customer and short term funding (liquid). ${ }^{6}$

\subsection{Relatedness variables}

Acquirers buy targets for a variety of reasons including a desire to expand into different geographic and different product markets. However, in many cases the acquirer may also believe that it has a superior business model to the target and plans implementing its model once

\footnotetext{
${ }^{6}$ This paper does not include the medium of payment in acquisitions (equity, cash, combination finance), because the available information is very limited in quantity and quality. Thomson Financial provides data on merger finance for less than half of sample deals. Means of payment data are mostly missing for acquisitions of non-listed targets and cannot be satisfactorily recovered from the news coverage surrounding a deal.
} 
the acquisition is complete. The adoption of the acquirer's model is likely to make the target's balance sheet look more like that of the acquirer. If the acquirer has a superior model, the target's earnings performance should also move towards that of the acquirer. Thus, our analysis also controls for the relatedness defined for financial variable $i$ as acquirer's value of $i$ at $t-1$ minus the target's value of $i$ at $t-1$. This variable is expected to have a value between zero and one. The extent of changes made by the target as it moves toward the acquirer's business model post-merger may depend in part on the existence of a prior relationship between the two firms. If the acquirer already had a toehold and used its ownership position to encourage changes in the target, the desired post merger changes in the target may be smaller. For example, if as a result of the acquirer's toehold position, the target has already started to reduce its liquidity towards the acquirer's level, the remaining adjustment in the target's capital should be smaller. Thus, the interaction of toe and the relatedness variable should have a negative coefficient.

\subsection{Regulatory variables}

One version of Carbo-Valverde et al. (2012) safety net exploitation hypothesis is that cross-border mergers per se give rise to regulatory arbitrage opportunities. If so, cross-borer deals where the bidder and target bank are chartered in separate countries $(c b)$ should be associated with the target bank and consolidated acquirer holding higher return, but also higher risk portfolios, implying a positive coefficient in roa equation. Safety net arbitrage may also lead to lower capital and liquidity, implying a negative coefficient in the dcapasset and dliqu regressions. Two other possibilities are that: (a) cross-border deals are no different from domestic takeovers implying insignificant coefficients on $c b$ in all three sets of regressions and (b) cross-border deals are more difficult to execute than domestic deals implying a negative 
coefficient in the roa equation and possibly also negative coefficients in the dcapasset and dliqu regressions.

All else equal, prudential supervisors prefer high capital, earnings and liquidity to reduce the risk that a bank could become insolvent or illiquid. The proxy for the prudential supervisors' ability to enforce their preferences on the bank is regul_strength. Thus, dcapasset and dliqu are expected to be positively correlated with regul_strength. The expected sign on droa is ambiguous. While supervisors may prefer higher profits, stricter regulation imposes compliance costs that may result in lower bank profits. As a possible offset, underperforming but viable targets would face greater supervisory pressure to sell themselves to sound and better performing acquirers in countries with stricter regulation. Such supervisory pressure would result in a positive correlation between the target's droa and regul_strength. Following Buch and Delong (2008) and Hagendorff et al. (2011), we compile an index of regulatory and supervisory strength based on the Barth et al. (2001) database on global banking supervision. The variable regul_strength is an index that reflects the adoption of twelve supervisory powers by national authorities and varies between 0 and 12 with higher values indicating stricter regimes. ${ }^{7}$

We compile an index of deposit insurance $(d i)$ that reflects the way in which the banks pay for their coverage based on data from the European Commission Joint Research Center (2008). The index reflects if (i) insurance premiums are risk-based, and (ii) the deposit

\footnotetext{
${ }^{7}$ The index values are based on answers ('yes'=1) to the following provisions: banks disclose risk management procedures; risk-weights are in line with Basle guidelines; the capital-asset ratio varies with credit risk; the capitalasset ratio varies with market risk; there is a formal definition of 'non-performing loan' (these components are related to prudential regulatory strength); there are automatic mechanisms to sanction directors and managers; the supervisory agency can order directors/management to make provisions to cover losses; the supervisory agency can suspend the distribution of dividends, bonuses, or management fees; the latter has been enforced in the past five years; the supervisory agency can declare a bank insolvent; the agency can suspend ownership rights of a problem bank; the supervisory agency (or any other government agency) can take measures aimed at bank restructuring and reorganization (these components are related to the enforcement powers of supervisors)
} 
guarantee scheme is pre-funded. The index varies between 0 and 2 . Higher values of $d i$ could be associated with the combined banking organization seeking to reduce its reliance on the national deposit insurance scheme. This implies a negative relationship between dliqu and di because high values of $d i$ would be associated with higher marginal cost of deposits of customers (premiums). In turn, a higher premium for more risky banks, however, would imply a positive relationship between dcapasset and di explained by the incentives to keep higher capital ratios.

If the takeover is across national boundaries, the acquirer's consolidated group will have more options for reducing regulatory and deposit insurance burdens after the merger via regulatory arbitrage. We model this effect interacting the binary variable $c b$ with both the difference in regul_strength between the acquirer and target $\left(c b^{*}\right.$ regul $)$ and the difference in $d i$ between the acquirer and the target $\left(c b^{*} d i\right)$. Thus, higher values of these interaction variables suggest that the prudential regulatory and deposit insurance environments are stricter in the acquirer's home country. The Carbo-Valverde et al. (2012) view would suggest that the acquirer engages in regulatory arbitrage by shifting to the extent possible the riskier and more profitable operations to the more lightly regulated target country. This shift would lead to an increase in the ROA of the target, implying a positive relationship between $\mathrm{d} r o a$ and the variables $c b^{*}$ regul and $c b^{*} d i$ in the target regression models.

Also, the shift of riskier operations to the target could result in a negative relationship between the target's diquid and the variables $c b^{*}$ regul and $c b^{*} d i$ to the extent that the target reduces liquid assets in favor of riskier and less liquid assets. However, the stricter home country regulator may also use its influence, via the acquirer, in order to strengthen its capitalization and liquidity. Hence, dcapasset and dliquid will have a positive correlation with $c b^{*} r e g u l$ and $c b^{*} d i$. To the extent that supervisors make their prudential assessments on a consolidated basis, the 
room for possible regulatory arbitrage and exploitation of host countries safety nets is reduced. Hence, either no statistically significant or significant and positive relationships are expected between the acquirer's dlever, and $\mathrm{d} l i q u$ and the regulatory interaction terms $c b^{*} r e g u l$ and $c b^{*} d i$. The impact on $\mathrm{d} R O A$ is more uncertain. A positive relationship would be explained either by the shifting of riskier and more profitable operations to the less regulated host country or by the benefits associated with the entrance in the host countries of franchises coming from stricter regulatory environments. A negative relationship between the acquirer's $\mathrm{d} R O A$ and the regulatory interaction terms $c b^{*}$ regul and $c b * d i$ could be explained by overall negative impact of higher regulatory costs.

The variable relsize measures the size of target relative to the acquiring bank. A low value of relsize indicates the target is joining a much larger acquirer which could influence market and supervisory evaluations. Markets may perceive that a larger acquirer is better able to come to the aid of a smaller target. If so, this perception would likely reduce the market pressure for higher capital and, all else equal, the cost of obtaining funding. However, consistent with Carbo et al. the acquisition by a larger acquirer could influence supervisors in two ways. First, to the extent that supervisors consider potential support from the group, a lower value for relsize implies the bank is likely to benefit from that support (strength of group hypothesis). A second influence on supervisory judgment is that a larger acquirer (smaller relsize) may have more influence with the supervisors to relax binding regulatory requirements on the target's capitalization and possibly liquidity standards (regulatory clout hypothesis) or the consolidated group may possibly exploit further the safety net for being considered "too-big-to-fail." The market valuing implicit support and the regulatory clout hypothesis have similar implications for our model. The coefficients on relsize are predicted to be positive in the droa, and negative in 
the dlever and possibly dliquid equations. The reverse holds for the acquirer, the larger relsize. The acquirer may gain some diversification benefit from a larger target and/or acquiring a larger target may give it more clout with its supervisor and greater government implicit support in a crisis (consistent with Carbo et al.). Thus, the predicted relationship for the acquirer is that of a negative correlation between dcapassets and dliquid with relsize. Similarly, a positive relationship for the acquirer would be expected between droa and relsize to the extent that the acquirer benefits from increased diverisification and/or an increase in perceived government implicit support.

\section{Data and univariate analysis}

\subsection{The sample}

We obtain the sample of European bank mergers (EU) from Thomson Financial's M\&A database. Deals are announced and completed between 1997 (year before the launching of the Euro) and 2007 (year before the Lehman collapse) and involve commercial banks, mortgage and real estate banks, medium- and long-term credit banks, and bank holding companies which are chartered in Europe (EU). We impose the following additional sampling criteria. The acquirer purchases at least $1 \%$ of the target's equity and all deals lead to the acquirer owning in excess of $20 \%$ of the target bank's equity. ${ }^{8}$ Sample banks are not subsidiaries of financial institutions chartered outside the EU. We eliminate share repurchases from our sample.

\footnotetext{
${ }^{8}$ A control threshold of less than $50 \%$ is consistent with both accounting and supervisory rules in the EU. Thus, IFRS accounting rules consider ownership of $20 \%$ as a permanent investment and EU prudential supervisors have set a $20 \%$ ownership level as a threshold beyond which supervisory authorization is required (see Directive 2007 / 44/ CE of the European Parliament).
} 
Target and acquiring banks accounting data are obtained from Fitch IBCA's Bankscope database. We ensured that accounting data are consistently reported in either International Financial Reporting Standards (IFRS) or local accounting principles for every deal. ${ }^{9}$ Bankscope does not allow us to determine whether and to what extent the target income statement and balance sheet are consolidated with the acquirer, excepting in those cases where the target charter is merged into the acquirer. ${ }^{10}$ However, given that our goal is to provide information on changes in the variables of interest to supervisors, the use of consolidated data is appropriate as these are the data that would be of most interest for prudential supervision.

From an initial sample of 388 deals, we then omit deals where acquirers had a majority shareholding in the target bank before the merger was announced (defined as acquirers owning more than 50\%). A majority ownership in the target means that bidding banks would have already exercised control before a deal. This affects 103 deals. Further, we exclude deals that

\footnotetext{
${ }^{9}$ IFRS have been introduced after 2004 and apply only to listed banks in our sample. IFRS introduced the fair value treatment of a larger variety of bank assets. Hence, combing different accounting standards for one bank may cause severe measurement errors. For example, Barclays experienced a year-on-year increase in the value of total assets of $30 \%$ following the adoption of IFRS.

${ }^{10}$ Acquirers may account for their stock holdings in the target in one of three ways: using standard investment method for portfolio holdings,(such as an available for sale (AFS) security), using the equity method, or consolidating the target with the acquirer. The equity method is required when the acquirer exerts significant influence over the target, with 20 percent or more creating a presumption of influence. The target must be consolidated if the acquirer controls the target, with the acquirer presumed to have control if it owns 50 percent or more. We can observe ownership interest using Bankscope. However, an acquirer may be deemed to exercise influence with less than 20 percent or to exercise control with less than 50 percent. Thus, we cannot be certain about how the acquirer is accounting for the target.

Under both AFS and the equity method, the acquirer only recognizes the value of its investment in the target on its balance sheet. Dividend payments are recognized in ordinary income under AFS but market value changes are recognized only to the extent of permanent losses. With the equity method, the acquirer recognizes its proportionate share of the net income (or loss) of the target. In contrast, with consolidated accounting, the acquirer and target are treated as a single entity. Thus, the consolidated balance sheet reflects each of the target's asset and liabilities, except to the extent these are due to or due from another part of the group that is also included in the consolidated statements (hence, loans from the parent would cancel out in consolidation). Similarly, the consolidated income statement would reflect the target's net income with intra-group transactions canceling out in consolidation and with a deduction for income attributable to the target's noncontrolling shareholders.
} 
involve failing targets from the sample. Whenever the price the acquirer pays values the equity of the target at less than its book value, we examine the press coverage surrounding a deal to gauge if the target was a failing bank. We omit 11 deals that we classify as involving failed targets

Where a bidder engages in multiple acquisitions involving the same target bank within the same fiscal year, we treat these transactions as a single deal. This affects 12 deals which are consolidated into six deals (net loss of six deals). ${ }^{11}$ As a final step, we require that data for the dependent variables (capitalization, liquidity, and performance) are available for both acquiring and target banks in $t-1$ in order to estimate measures of relatedness between the merging firms as explained in Section 3. ${ }^{12}$

Our final sample contains 103 acquiring banks and 84 target institutions. We have fewer target institutions because many of them stopped reporting financial information because they were merged into the acquirer. We verified that our sample selection procedure does not suffer from a bias (e.g. when targets which were fully absorbed differ substantially from targets which were not absorbed). We tested if the financial and deal data vary by whether the target has subsequently been absorbed by the acquiring bank. We find no statistically significant differences between the two subsets. We present an overview of the full sample of targets and acquirers per country and year in Table 1 .

\footnotetext{
${ }^{11}$ For consolidated deals, the deal-specific variables "percentage acquired" and "deal size" are the sum of the component deals.

${ }^{12}$ Our sampling strategy retains deals where bidders engage in more than a single deal during our examination period of up to two years after the completion of a deal. This treatment of repeat acquisitions is consistent with the literature. Similar to us, Ibañez and Altunbas (2004), Campa and Hernando (2006), Beccalli and Frantz (2009), Vander Vennet (1996), and Diaz et al. (2004) make no adjustments regarding multiple deals.
} 


\subsection{Descriptive analysis of targets and acquirers in EU M\&As}

Descriptive statistics and univariate analyses are provided in Tables 2-4. Table 2 compares targets and acquirers in the year before the deal was completed. Table 3 analyzes changes in the same performance ratios over the time period -1 to +2 years relative to the completion year of a deal in order to "isolate" the financial impact of each particular M\&A. Merger-related changes are presented both in absolute (Panel A) and in industry-adjusted form (i.e. relative to the median values of the banks' market; Panel B). Industry-adjusted indicators of the safety and soundness of banks are of particular significance for bank supervisors, because these show changes in key indicators relative to the market. ${ }^{13}$ Finally, Table 4 presents the summary statistics of the variables included in the regression.

The comparison of targets and acquirer's in Table 2 shows that targets had higher absolute capital ratios pre-merger than acquirers. Targets have significantly higher absolute values for all three capital ratios in Panel A and higher industry-adjusted values for all but the risk weighted capital ratio (Panel B). The regression analysis in this paper focuses on the capital to total asset ratio (capasset) because the other two measures (tier 1 capital to risk weighted assets $[$ tr $r w a]$ and total capital to risk weighted assets [totalrwa]) are available for far fewer targets and are subject to regulatory differences on the assessment of risk weighted assets. Further, the liquid funds ratios (liquid) and return on assets (ROA) are not statistically significantly different from each other in either absolute or industry adjusted terms. Further,

\footnotetext{
${ }^{13}$ In unreported tests, we examine how acquirer and target banks differ from the industry benchmark (i.e. median industry values) in the key safety and soundness indicators we investigate in this study. The results of $t$-tests show that both acquirers and targets have lower equity to assets ratios (as well as lower holdings of Tier 1 and total capital relative to total assets) and lower liquidity ratios relative to their respective industry benchmarks. In the case of acquirers, these differences are larger than for targets for each of these variables. Further, acquirers outperform the markets in terms of ROA, while the pre-merger performance of target banks is statistically indistinguishable from the industry benchmark.
} 
acquirers are also less reliant on net interest income (interest) and thus boast a business model with a wider range of income sources than target banks.

Merger related changes in capital, liquidity, earnings and reliance on net interest income are shown in Table 3. The results of Panel A provide evidence of no statistically significant impact of the M\&A on the acquirer's capital, liquidity or earnings in absolute terms. While the industry adjusted ratios show a statistically significant albeit small deterioration of the acquirers' profitability immediately after the merger $(\mathrm{d} R O A)$. Panel B shows an increase in the target's capital of approximately $0.20 \%$ (both in absolute and industry adjusted terms). This is consistent with supervisors requiring acquirers of undercapitalized banks to raise the target's capital ratio. No other change in the target financial ratios is statistically significant.

Table 4 provides selected summary statistics for our sample of acquiring (Panel A) and target banks (Panel B). The mean values of the cross-border binary variable, $c b$, indicates that about 42 percent of the observations consist of cross-border transactions. The target's assets averaged approximately 30 percent of that of the acquirer (relsize). The mean values of the toe hold variable toe indicates that the acquirer had a previous ownership interest in approximately 15-18 percent of the observations.

\section{Model estimation}

\subsection{Acquirer model results}

Table 5 presents the empirical results of our estimations based on the model for acquirer changes in capitalization with the first two columns of Table 5 give results of estimating the absolute change in leverage whereas the second two columns give the estimation results where the dependent variable is measured relative to its home country industry. Columns 1 and 3 
provide estimation of a base model with only the lagged adjustment (mean reversion) and the two relatedness variables. This provides a baseline to determine the explanatory power of a simple model. Columns 2 and 4 then provide estimates of the complete model.

The coefficient on lagged acquirer leverage shows consistently significant mean reversion of between 15 and 34 percent. As predicted, the interaction of toehold ownership (toe) and relative leverage (relatlev) is negative but smaller in size.

The coefficient on the binary variable for cross-border mergers is significantly negative for both absolute and industry-adjusted values. This provides some evidence consistent with Carbo-Valverde et al. (2012) that cross-border mergers are associated with greater risk to the safety net after controlling for other factors. An alternative interpretation is that acquirers in cross-border mergers went to greater efforts pre-merger to boost their capital levels to obtain supervisory approval of the takeover.

The coefficient on deposit insurance, $d i$, is significantly negative in the absolute value but its interaction with cross-border is significantly positive. The negative coefficient on $d i$ is not what would be predicted regardless of whether one views bank mergers as an attempt to exploit the safety net. The positive coefficient on the interaction term suggests that capital fell less if the acquirer's $d i$ takes a larger value than the target's $d i$. This result seems to qualify our previous interpretation of the negative coefficient of $c b$ regarding the potential larger risk to the safety net.

The estimation results for the acquirer's earning performance are in Table 6. Acquirer performance shows strong mean reversion ranging from 57 to 79 percent. This high mean reversion could merely reflect normal statistical mean reversion. Or it could reflect actions taken by the acquirer to boost its reported earnings prior to the merger in an effort to impress the supervisors and investors. The interaction term on cross-border mergers is negative, which is 
consistent with greater difficulties in integrating cross border deals but not with the acquiring group using the cross-border deal to invest in higher return/higher risk assets as implied by safety net exploitation. The coefficient on regulatory strength (regul_strength) is significantly positive in the industry-adjusted equation. The coefficients on the interactions of cross-border with regulatory strength and deposit insurance are all significantly positive. One interpretation is that acquirers benefit from the reputation of their home country supervisor when it is tougher than the host country supervisor.

The coefficient on $h h i$ is significantly negative in the industry adjusted equation but insignificant in absolute terms.

Table 7 reports the results for changes in the acquirer's liquidity. Liquidity shows signs of very high mean reversion. While all of the mean reversion coefficients are significantly greater than zero, none are significantly different from one. This could reflect some combination of: (a) some acquirers taking measures to temporarily boost their premerger liquidity for precautionary purposes including payment of the acquirers' shares in cash, and (b) those banks that were reporting weak premerger performance needing to demonstrate to their supervisors prior to the merger that they were on a positive trend to get the deal approved. The relatedness variable of liquidity (difference between acquirer and target in $t-1$ ) when interacted with toehold in the target premerger is positively correlated with the acquirer's liquidity after the merger. This could be explained by the acquirer's build up of liquidity for potential additional acquisitions of target shares. As shown in Hernando, Nieto and Wall (2009) staggered shareholding acquisitions of banks is common in the EU. ${ }^{14}$

\footnotetext{
${ }^{14}$ Hernando, Nieto and Wall (2009) show that, in their sample, once an acquirer has more than $20 \%$ it ultimately buys at least $50 \%$ of the target during the study period.
} 
Regulatory strength has a negative coefficient in absolute terms contrary to predictions but the coefficient is insignificant in industry adjusted terms. Both interactions with $c b$ (regulatory strength and deposit insurance) are significantly positive. ${ }^{15}$ Lastly, our results show a statistically significant procyclicality of liquidity in the period immediately after the merger.

Overall, these results most strongly suggest that our measures of acquirers' financial condition exhibit moderate to strong mean reversion. This could reflect some combination of: (i) some acquirers taking measures to temporarily boost their premerger performance in order to improve their bargaining position, and (ii) those banks that were reporting weak premerger performance needed to demonstrate to their supervisors prior to the merger that they were on a positive trend to get the deal approved. ${ }^{16}$ The next strongest finding is that acquirer's showed more improvement in their post-merger earnings performance if their supervisor and deposit insurance funding system were stronger than that of the target. This result is consistent with the group benefiting from importing the acquirer's stronger supervision into the target (such as through a lower cost of funds). If so, we should observe similar results in the model estimating post-merger changes in target earnings performance. An alternative is that stricter home country supervision may be more effective in preventing acquirers from engaging in takeovers that would result in a weak post-merger group.

\footnotetext{
${ }^{15}$ The estimated effects for the regulatory variables in the case of cross-border deals are not significantly different from zero. In unreported tests, we cannot reject the hypothesis that the sum of the coefficients on the regulatory strength index and the corresponding interaction term is zero

${ }^{16}$ In unreported tests, we seek to verify whether acquirers temporarily boosted their financial condition pre-merger before reverting to their pre-merger levels shortly afterwards. We indeed find negative correlations for changes between years -3 and -1 and +1 and +3 in leverage $(r=-0.15)$, ROA $(r=-0.23)$ and liquidity $(r=-0.44$, significantly different from zero at $5 \%$ ). However, with the exception of liquidity, the correlations remain modest in magnitude.
} 


\subsection{Target model results}

The results with the target variables are presented in Tables 8-10. The results for target capitalization are not very informative about the cross-sectional distribution of leverage changes. The mean reversion coefficients are negative and large in absolute magnitude, larger than those for the acquirer. The only significant coefficients are the coefficients on deposit insurance, which is consistent with expectations. However, the f-tests for the joint significance of the coefficients fail to reject the hypothesis that they are all equal to zero in all equations.

The results for target earnings performance are presented in Table 9. Again the mean reversion coefficients are moderately large but very imprecisely measured; none of them are statistically significant. However, the coefficients on relative earnings (acquirer roa minus target roa) are consistently significant and economically large in industry adjusted terms (only in the first equation in absolute terms). Targets move approximately 50 to 60 percent of the way towards the roa levels of their acquirer. The coefficients on hhi are consistently negative suggesting that profits dip in the period immediately after the merger either because management disruption results in a temporary loss of economic rents or because deliberately higher asset growth at the expense of profitability allows to better exploit concentrated markets.

Greater regulatory strength and tougher deposit insurance are generally associated with significantly higher profits. One interpretation of this is that stronger supervisors encourage less profitable banks to sell themselves to stronger banks. This hypothesis receives some support from the low profitability of some of the targets in our sample. The mean roa at t-1 for bottom quartile of targets in our sample as measured by roa, is -0.48 percent and these banks show an increase in ROA of 0.605 p.p. from $t-1$ to $t+2$. However, the average values of regulatory strength and deposit insurance indexes for target banks in the bottom quartile are not 
significantly different from the average of all targets. None of the interactions with cross-border are statistically significant. These findings fail to support the hypothesis that the target's performance benefits from the importing of the stricter supervision of its new parent's supervisor.

The results for liquidity reported in Table 10 suggest strong reversion towards the mean for target liquidity. Some other variables are significant in the absolute value equations and other are significant in the industry-adjusted equations, but none are significant in both. If the acquirer had a toe hold in the target, the absolute measure of liquidity tended to decrease.

The strongest consistent set of results across the target equations is that stronger supervision and tougher deposit insurance funding regimes tend to result in positive changes for the target's liquidity. One interpretation of this is that stricter supervisors and deposit insurance regimes tend to encourage weak banks to sell themselves to stronger acquirers.

\section{Conclusions and policy implications}

Bank M\&As both within and among EU countries gathered considerable momentum with the introduction of the Euro. In spite of this, there is a considerable dearth of studies that focus on the short term impact of M\&As on the capitalization, earnings and liquidity of both targets and acquirers. This paper attempts to bridge that gap by analyzing a sample of European bank mergers (EU) which were completed between 1997 and 2007. Our sample contains accounting data for both acquiring and target banks over the examination period of -1 to +2 years around the completion date of a deal in order to isolate the impact of the M\&A.

In terms of policy implications, we find that M\&A activity has a generally insignificant impact on our safety and soundness indicators, with the biggest exception being an increase in the leverage ratio (capital to assets ratio) for targets (significant at the 10 percent level). 
However, looking cross-sectionally, we frequently find that the acquirer and to a lesser extent the target become financially stronger if the acquirer's home country supervision is stronger than the targets. One hypothesis is that this is a result of the target importing the reputational benefits associated with the stricter regime imposed by the acquirer's consolidating supervisor. This hypothesis is not supported by evidence that the target's profitability is significantly positively correlated with stricter supervision of the acquirer relative to the target. An alternative hypothesis that is consistent with both findings is that relatively stricter supervision of the acquirer is more likely to prevent acquirers from making bad takeovers. Thus, while our evidence does not support the case that M\&A is generally good or bad for bank safety and soundness; it does support the case that strict consolidating supervisors results in better takeovers.

Our paper also has important methodological implication for the future analysis of bank M\&A: the empirical design should account for the possibility of mean reversion to a greater extent. We find strong evidence of mean reversion for the acquirer that should be taken into account in the research design. Additionally, we also find evidence consistent with significant mean reversion in the target, albeit in many cases our measures are not very precise. 


\section{References}

Altunbas, Y. \& Marqués D., 2008. Mergers and Acquisitions and Bank Performance in Europe: The Role of Strategic Similarities, Journal of Economics and Business, 60(3), 204-222.

Amel D, Barnes C, Panetta F, Salleo C (2004) Consolidation and efficiency in the financial sector: a review of the international evidence. Journal of Bank and Finance 28:24932519.

Barth, J. R., Caprio, G., Levine, R., 2001. Banking Systems around the Globe: Do Regulation and Ownership Affect Performance and Stability? In Prudential Supervision : What Works and What Doesn't, ed. F. S. Mishkin, University of Chicago Press. Chicago.

Beccalli,E \& Frantz, P. (2009) M\&A operations and performance in banking, Journal of Financial Services Research 36, 203- 226.

Beitel, P. Schiereck, D. Wahrenburg, M. (2004), Explaining M\&A Success in European Banks, European Financial Management, 10(1), 109-139.

Benston, George J \& Hunter, William C \& Wall, Larry D, 1995. Motivations for Bank Mergers and Acquisitions: Enhancing the Deposit Insurance Put Option versus Earnings Diversification, Journal of Money, Credit and Banking, 27(3), 777-88.

Berger, Allen N. \& Demsetz, Rebecca S. ,Strahan, Philip E., 1999. "The consolidation of the financial services industry: Causes, consequences, and implications for the future," Journal of Banking \& Finance, 23, (February), 135-194.

Berger, A, \& Bouwman C., 2009. Bank Liquidity Creation Review of Financial Studies , 22(9), 3779-3837.

Brewer III, E. and Julapa, J., 2007. How Much Would Banks Be Willing to Pay to Become 'Too-Big-to-Fail' and to Capture Other Benefits? Federal Reserve Bank of Kansas City Working Paper RWP 07-05 (July).

Buch, C. M. \& DeLong, G., 2008. Do Weak Supervisory Systems Encourage Bank Risk-Taking? Journal of Financial Stability 4, 23-39.

Cabral, I., Dierick, F., \&Vesala, J., 2002. Banking integration in the euro area. European Central Bank Occasional Paper 6.

Campa, J. M. \& Hernando, I. 2006. M\&As Performance in the European Financial Industry, Journal of Banking \& Finance, 30(12), 3367-3392.

Carbo-Valverde, S., Kane, E and Rodriguez-Fernandez , F. (2008). Evidence of Differences in the Effectiveness of Safety-Net Management in European Union Countries. Journal of Financial Services Research, 34, 151-76. 
Carbo-Valverde, S., Kane E. and Rodriguez-Fernandez F. (2012). Evidence of regulatory arbitrage in cross-border mergers of banks in the EU. Journal of Money, Credit \& Banking, forthcoming.

Cheng, D. C., Gup, B. E. and Wall, L. D. (1989). Financial Determinants of Bank Takeovers. Journal of Money, Credit and Banking, 21 (4), 524-536.

de Haas, R. \& van Lelyveld, I., 2006. Foreign Banks and Credit Stability in Central and Eastern Europe. A Panel Data Analysis. Journal of Banking \& Finance 30, 1927-1952.

DeYoung, Robert; Evanoff Douglas; Molyneux, Philip, 2009, Mergers and Acquisitions of Financial Institutions: A Review of the Post-2000 Literature Journal of Financial Services Research, 36, 87-110.

Díaz, B., García M., Sanfilippo S., 2004. Bank acquisitions and performance: evidence from a panel of European credit entities, Journal of Economics and Business 56, 377-404.

Fama, E.F., French, K.R., 2000. Forecasting profitability and earnings. Journal of Business 73, 161-175.

European Commission Joint Research Center Unit G09, 2008, Investigating the efficiency of EU Deposit Guarantee Schemes, Ispara Italy, (May), accessed on October 19, 2010 at http://ec.europa.eu/internal_market/bank/docs/guarantee/deposit/report_en.pdf .

Hagendorff, J, Collins M .and Keasey K. (2008). Investor protection and the value effects of bank merger announcements in Europe and the US, Journal of Banking and Finance 32, 1333-1348.

Hagendorff J., Hernando I., Nieto M. \& Wall, L, 2012. What Do Premiums Paid for Bank M\&As Reflect? The Case of the European Union. Journal of Banking \& Finance, 36, 749-759.

Hagendorff, J., Keasey, K. (2009), Post-Merger Strategy and Performance: Evidence from the US and European Banking Industries, Accounting and Finance 49, 725-751.

Hannan, Timothy H., Pilloff, Steven J., 2009. Acquisition Targets and Motives in the Banking Industry, Journal of Money, Credit and Banking, 41(6), 1167-118.

Hernando, I., Nieto, M.J., Wall, L.D., 2009. Determinants of domestic and cross-border bank acquisitions in the European Union. Journal of Banking \& Finance. 33, 1022-1032.

Houston, J. F. \& James, C., 1998. Do Bank Internal Capital Markets Promote Lending? Journal of Banking \& Finance 22, 899-918.

Jones KD, Critchfield T (2005) Consolidation in the U.S. banking industry: is the 'long, strange trip' about to end? FDIC Bank Rev 17:31-61.

Knapp M, Gart A, Becher D (2005) Post-merger performance of bank-holding companies 19871998. Financial Review 40:549-574. 
Mayes, D. G., Nieto, M. J. \& Wall, L., 2008. Multiple Safety Net Regulators and Agency Problems in the EU: Is Prompt Corrective Action Partly the Solution? Journal of Financial Stability 4, 232-257

Molyneux, P, Schaeck, K., and Zhou, T. 2010. Too-Big-to-Fail” and Its Impact on Safety Net Subsidies and Systemic Risk. Bangor, Wales: Bangor University Working Paper .

Rhoades, Stephen A., 1994, A summary of merger performance studies in banking, 1980-93, and an assessment of the "operating performance" and "event study" methodologies, Staff Studies 167, Board of Governors of the Federal Reserve System (U.S.).

Vander Vennet, R.,(1996) The Effect of Mergers and Acquisitions on the Efficiency and Profitability of EC Credit Institutions. Journal of Banking \& Finance 20, 1531-1558.

Vander Vennet R (2002) Cross-border mergers in European banking and bank efficiency. Universiteit Gent Working Paper 2002/152, December. 
Table 1 Sample Description

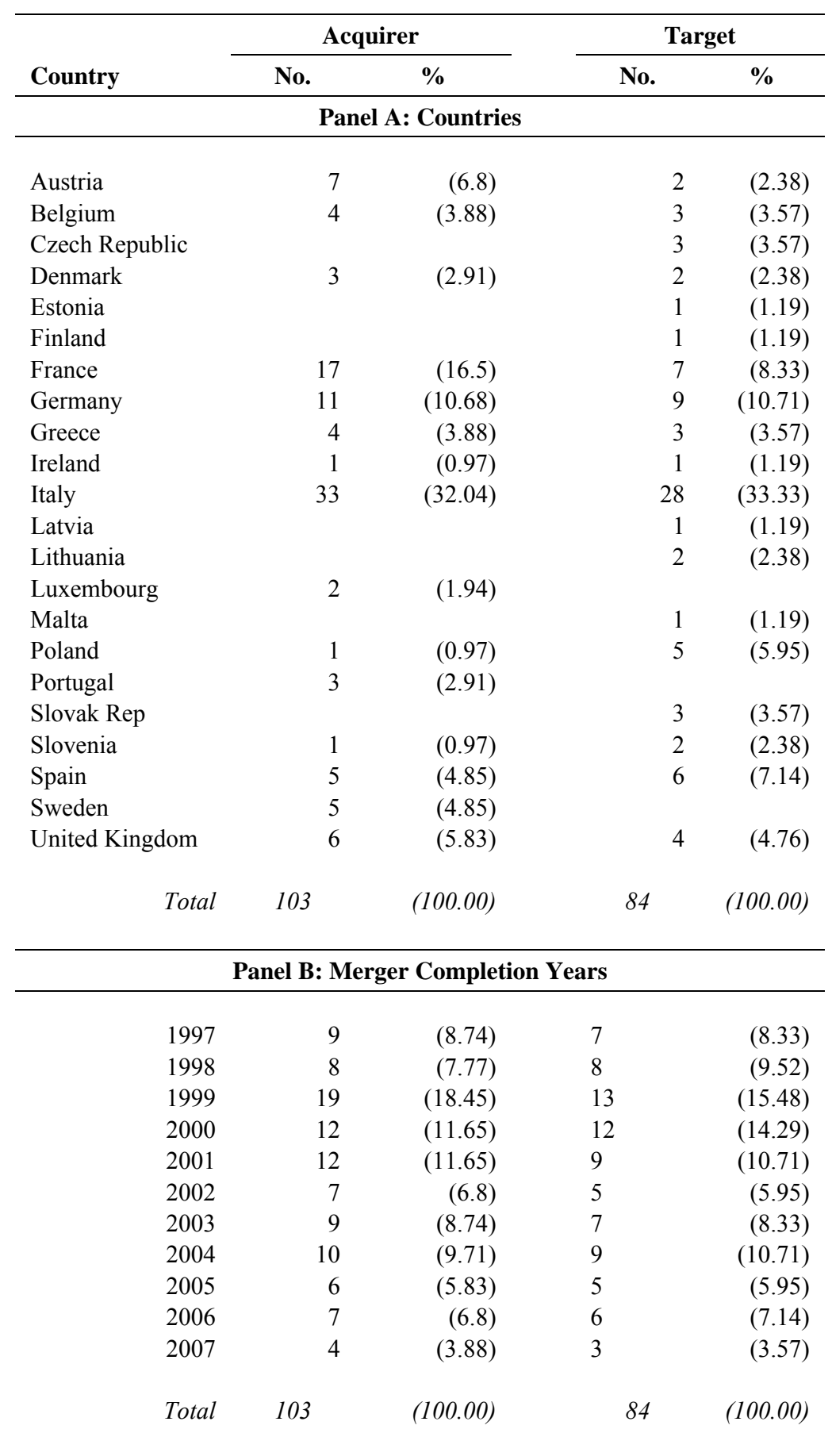

Years refer to the year of merger completion as supplied by Thomson Financial. 
Table 2 Target and Bidding Bank Characteristics Pre-M\&A

\begin{tabular}{|c|c|c|c|c|c|c|}
\hline & \multicolumn{6}{|c|}{ Difference } \\
\hline & $\mathbf{N}$ & Acquirer & Target & Acquirer-Target & $t$-Stat & p-Value \\
\hline \multicolumn{7}{|c|}{ Panel A: Absolute Values } \\
\hline capasset & 79 & 4.935 & 7.614 & -2.680 & $(-4.69)^{* * *}$ & 0.00 \\
\hline tlrwa & 38 & 8.695 & 11.717 & -3.022 & $(-2.51)^{* *}$ & 0.02 \\
\hline totalrwa & 47 & 10.874 & 13.481 & -2.607 & $(-2.69)^{* * *}$ & 0.01 \\
\hline liquid & 70 & 22.846 & 25.354 & -2.508 & $(-0.89)$ & 0.38 \\
\hline roa & 79 & 0.529 & 0.638 & -0.109 & $(-0.93)$ & 0.36 \\
\hline interest & 79 & 57.400 & 67.292 & -9.892 & $(-4.71)^{* * *}$ & 0.00 \\
\hline \multicolumn{7}{|c|}{ Panel B: Industry-adjusted Values } \\
\hline capasset & 79 & -3.374 & -1.418 & -1.956 & $(-3.39)^{* * *}$ & 0.00 \\
\hline t1rwa & 38 & -4.103 & -1.901 & -2.202 & $(-1.93)^{*}$ & 0.06 \\
\hline totalrwa & 46 & -3.849 & -2.406 & -1.443 & $(-1.41)$ & 0.17 \\
\hline liquid & 70 & -5.955 & -8.210 & 2.255 & $(0.67)$ & 0.51 \\
\hline roa & 79 & -0.085 & -0.098 & 0.013 & $(0.12)$ & 0.90 \\
\hline interest & 79 & -40.866 & -30.483 & -10.382 & $(-3.60) * * *$ & 0.00 \\
\hline
\end{tabular}

Capasset is the equity to assets ratio, tlrwa is the tier 1 capital to risk-weighted assets ratio and totalrwa is total regulatory capital to risk-weighted assets. Roa is return on assets and interest is net interest income over total operating income. All values refer to the last fiscal year before the acquisition completion. * significant at $10 \% ; * *$ significant at $5 \% ; * * *$ significant at $1 \%$ 
Table 3 Merger-related changes for targets and acquirers

\begin{tabular}{|c|c|c|c|c|c|c|c|c|}
\hline & \multicolumn{4}{|c|}{ Absolute Differences } & \multicolumn{4}{|c|}{ Industry-Adjusted Differences } \\
\hline & $\mathbf{N}$ & change & $t$-Stat & p-value & $\mathbf{N}$ & change & $t$-Stat & p-value \\
\hline \multicolumn{9}{|c|}{ Panel A: Acquiring Banks } \\
\hline$d$ capasset & 103 & 0.142 & 1.01 & 0.32 & 103 & -0.260 & -1.24 & 0.22 \\
\hline$d$ t1rwa & 85 & -0.342 & -1.39 & 0.17 & 85 & -0.048 & -0.16 & 0.87 \\
\hline$d$ totalrwa & 91 & -0.049 & -0.21 & 0.84 & 91 & 0.325 & 1.16 & 0.25 \\
\hline$d$ liquid & 93 & -0.631 & -0.19 & 0.85 & 93 & 3.529 & 1.04 & 0.30 \\
\hline droa & 103 & -0.054 & -1.43 & 0.16 & 103 & -0.068 & $-1.65^{*}$ & 0.10 \\
\hline dinterest & 103 & -10.414 & -0.82 & 0.41 & 103 & -9.406 & -0.74 & 0.46 \\
\hline \multicolumn{9}{|c|}{ Panel B: Target Banks } \\
\hline$d$ capasset & 84 & 1.189 & $1.60 *$ & 0.09 & 84 & 1.225 & $1.66^{*}$ & 0.10 \\
\hline$d$ t1rwa & 47 & -0.055 & -0.05 & 0.96 & 47 & 0.409 & 0.38 & 0.71 \\
\hline$d$ totalrwa & 56 & 0.217 & 0.25 & 0.80 & 55 & 0.706 & 0.77 & 0.44 \\
\hline dliquid & 81 & -1.742 & -0.67 & 0.50 & 81 & 3.033 & 1.15 & 0.25 \\
\hline droa & 84 & -0.003 & -0.02 & 0.98 & 84 & 0.031 & 0.27 & 0.79 \\
\hline dinterest & 84 & -4.518 & -1.13 & 0.26 & 84 & -2.584 & -0.62 & 0.54 \\
\hline
\end{tabular}

The table reports differences in safety and soundness variables which are due to M\&A. Differences are computed as values in +2 year minus values in -1 year relative to the merger completion year. Industryadjusted values are expressed based on median values of banks chartered in the same country. Capasset is the equity to assets ratio, t1rwa is the tier 1 capital to risk-weighted assets ratio and totalrwa is total regulatory capital to risk-weighted assets, liquid are liquid assets over customer and short-term deposits. Roa is return on assets and interest is net interest income over total operating income. All values refer to the last fiscal year before the acquisition completion. * significant at $10 \% ; * *$ significant at $5 \%$ 
Table 4 Summary Statistics

\begin{tabular}{|c|c|c|c|c|c|c|}
\hline & $\mathbf{N}$ & Mean & SD & p50 & p25 & p75 \\
\hline \multicolumn{7}{|c|}{ Panel A: Acquiring Banks } \\
\hline$d$ capasset & 103 & 0.142 & 1.428 & 0.105 & -0.433 & 0.766 \\
\hline dliquid & 93 & -0.631 & 31.983 & -3.620 & -13.970 & 1.930 \\
\hline droa & 103 & -0.054 & 0.388 & -0.060 & -0.280 & 0.140 \\
\hline lever $\mathrm{t}_{\mathrm{t}-1}$ & 103 & 5.337 & 2.738 & 4.374 & 3.380 & 6.487 \\
\hline liquid $_{t-1}$ & 93 & 23.978 & 14.712 & 21.750 & 14.830 & 28.810 \\
\hline roa $_{t-1}$ & 103 & 0.600 & 0.424 & 0.520 & 0.330 & 0.810 \\
\hline regul_strength & 101 & 5.525 & 1.906 & 5.000 & 4.000 & 6.000 \\
\hline $\mathrm{di}$ & 103 & 1.262 & 0.610 & 1.000 & 1.000 & 2.000 \\
\hline hhi & 103 & 0.084 & 0.063 & 0.060 & 0.044 & 0.105 \\
\hline gdpgrwth & 103 & 2.347 & 1.585 & 1.925 & 1.343 & 3.364 \\
\hline $\mathrm{cb}$ & 103 & 0.398 & 0.492 & 0.000 & 0.000 & 1.000 \\
\hline relsize & 103 & 0.229 & 0.406 & 0.040 & 0.013 & 0.229 \\
\hline toe & 103 & 0.155 & 0.364 & 0.000 & 0.000 & 0.000 \\
\hline \multicolumn{7}{|c|}{ Panel B: Target Banks } \\
\hline$d$ capasset & 84 & 1.189 & 6.814 & -0.082 & -1.536 & 1.853 \\
\hline dliquid & 81 & -1.742 & 23.278 & -2.780 & -11.410 & 8.040 \\
\hline droa & 84 & -0.003 & 1.130 & -0.005 & -0.450 & 0.405 \\
\hline capasset $_{\mathrm{t}-1}$ & 84 & 7.629 & 5.137 & 6.978 & 4.663 & 9.294 \\
\hline liquid $_{t-1}$ & 83 & 26.470 & 20.907 & 22.070 & 12.190 & 36.020 \\
\hline roa $_{\mathrm{t}-1}$ & 84 & 0.637 & 1.026 & 0.545 & 0.230 & 0.970 \\
\hline regul_strength & 78 & 5.897 & 1.777 & 5.000 & 5.000 & 7.000 \\
\hline $\mathrm{di}$ & 81 & 1.136 & 0.518 & 1.000 & 1.000 & 1.000 \\
\hline hhi & 84 & 0.102 & 0.096 & 0.075 & 0.044 & 0.126 \\
\hline gdpgrwth & 84 & 2.719 & 1.545 & 2.665 & 1.439 & 3.840 \\
\hline $\mathrm{cb}$ & 84 & 0.417 & 0.496 & 0.000 & 0.000 & 1.000 \\
\hline relsize & 84 & 0.295 & 1.036 & 0.039 & 0.012 & 0.206 \\
\hline toe & 84 & 0.179 & 0.385 & 0.000 & 0.000 & 0.000 \\
\hline
\end{tabular}

The prefix $d$ denotes differences in variables which are computed as values in +2 year minus values in -1 year relative to the merger completion year. Capasset is the equity to assets ratio, tlrwa is the tier 1 capital to risk-weighted assets ratio and totalrwa is total regulatory capital to risk-weighted assets, liquid are liquid assets over customer and short-term deposits. Roa is return on assets and interest is net interest income over total operating income, regul_stregnth is the an index of regulatory strength, di an index of deposit insurance regime, gdpgwrth is real GDP growth, $\mathrm{cb}$ is a dummy which is one if the deal is a cross-border deal (and zero otherwise), relsize are target assets divided by acquiring bank assets and toe is a binary variable which is one if the acquirer owns some equity in the target before the focal acquisition (and zero otherwise). 
Table 5 Regressions on Merger-related changes in Acquirer Capitalization

\begin{tabular}{|c|c|c|c|c|}
\hline & \multicolumn{2}{|c|}{ Absolute Values } & \multicolumn{2}{|c|}{ Industry-adjusted Values } \\
\hline & (1) & $(2)$ & (3) & (4) \\
\hline lever ${ }_{t-1}$ & $\begin{array}{l}-0.142 * * * \\
(2.71)\end{array}$ & $\begin{array}{l}-0.260 * * * \\
(3.38)\end{array}$ & $\begin{array}{l}-0.345^{* * *} \\
(3.85)\end{array}$ & $\begin{array}{l}-0.304 * * * \\
(3.28)\end{array}$ \\
\hline relatlever & $\begin{array}{l}0.067 \\
(1.58)\end{array}$ & $\begin{array}{l}0.015 \\
(0.16)\end{array}$ & $\begin{array}{l}0.111 \\
(0.94)\end{array}$ & $\begin{array}{l}0.115 \\
(0.97)\end{array}$ \\
\hline toe*relatlever & $\begin{array}{l}-0.078^{* * *} \\
(3.67)\end{array}$ & $\begin{array}{l}-0.087 * * \\
(2.40)\end{array}$ & $\begin{array}{l}-0.095^{* * *} \\
(3.38)\end{array}$ & $\begin{array}{l}-0.129^{* * * *} \\
(4.33)\end{array}$ \\
\hline relsize & & $\begin{array}{l}0.342 \\
(0.68)\end{array}$ & & $\begin{array}{l}-0.129 \\
(0.27)\end{array}$ \\
\hline toe & & $\begin{array}{l}-0.075 \\
(0.19)\end{array}$ & & $\begin{array}{l}1.044 * * \\
(2.02)\end{array}$ \\
\hline $\mathrm{cb}$ & & $\begin{array}{l}-0.604^{* *} \\
(2.17)\end{array}$ & & $\begin{array}{l}-0.991 * * \\
(2.18)\end{array}$ \\
\hline regul_strength & & $\begin{array}{l}-0.175 \\
(0.89)\end{array}$ & & $\begin{array}{l}0.310 \\
(1.29)\end{array}$ \\
\hline di & & $\begin{array}{l}-1.153^{* *} \\
(2.38)\end{array}$ & & $\begin{array}{l}-0.394 \\
(0.85)\end{array}$ \\
\hline $\mathrm{cb}^{*}$ regul & & $\begin{array}{l}0.014 \\
(0.10)\end{array}$ & & $\begin{array}{l}-0.225 \\
(1.10)\end{array}$ \\
\hline $\mathrm{cb}^{*} \mathrm{di}$ & & $\begin{array}{l}0.631 * \\
(1.73)\end{array}$ & & $\begin{array}{l}0.041 \\
(0.08)\end{array}$ \\
\hline hhi & & $\begin{array}{l}-0.842 \\
(0.27)\end{array}$ & & $\begin{array}{l}-5.501 \\
(1.44)\end{array}$ \\
\hline gdpgrwth & $\begin{array}{l}-0.088 \\
(1.41)\end{array}$ & $\begin{array}{l}-0.054 \\
(0.55)\end{array}$ & $\begin{array}{l}-0.096 \\
(0.84)\end{array}$ & $\begin{array}{l}-0.122 \\
(0.85)\end{array}$ \\
\hline Constant & $\begin{array}{l}0.925^{* * * *} \\
(3.08)\end{array}$ & $\begin{array}{l}3.970 * * \\
(2.41)\end{array}$ & $\begin{array}{l}-1.327 * * * \\
(2.86)\end{array}$ & $\begin{array}{l}-1.815 \\
(1.01)\end{array}$ \\
\hline Observations & 103 & 91 & 103 & 91 \\
\hline Adj. R-squared & 0.184 & 0.244 & 0.292 & 0.339 \\
\hline F-Stat & 5.19 & 2.93 & 4.93 & 4.17 \\
\hline
\end{tabular}

The dependent variable is merger-related change in return on acquirer capitalization from -1 to +2 years relative to the merger completion year. The prefix relat denotes similarities between acquirer and acquirer measured as acquirer values minus target values in one fiscal year before the acquisition. Bank controls refer to the acquiring bank. Capasset is the equity to assets ratio, t1rwa is the tier 1 capital to riskweighted assets ratio and totalrwa is total regulatory capital to risk-weighted assets, liquid are liquid assets over customer and short-term deposits. Roa is return on assets and interest is net interest income over total operating income. Country controls refer to the acquirer country in the year of the acquisition completion. regul_stregnth is the an index of regulatory strength, di an index of deposit insurance regime, gdpgwrth is real GDP growth, cb is a dummy which is one if the deal is a cross-border deal (and zero otherwise), relsize are target assets divided by acquiring bank assets and toe is a binary variable which is one if the acquirer owns some equity in the target before the focal acquisition (and zero otherwise).Robust $t$ statistics in parentheses.

* significant at $10 \%$;* significant at $5 \%$; ** significant at $1 \%$ 
Table 6 Regressions on Merger-related changes in Acquirer Performance

\begin{tabular}{|c|c|c|c|c|}
\hline & \multicolumn{2}{|c|}{ Absolute Values } & \multicolumn{2}{|c|}{ Industry-adjusted Values } \\
\hline & (1) & $(2)$ & (3) & (4) \\
\hline roa $_{\mathrm{t}-1}$ & $\begin{array}{l}-0.570 * * * \\
(3.90)\end{array}$ & $\begin{array}{l}-0.654 * * * \\
(3.64)\end{array}$ & $\begin{array}{l}-0.760 * * * \\
(6.08)\end{array}$ & $\begin{array}{l}-0.786^{* * *} \\
(5.17)\end{array}$ \\
\hline relatroa & $\begin{array}{l}0.002 \\
(0.03)\end{array}$ & $\begin{array}{l}-0.096 \\
(1.31)\end{array}$ & $\begin{array}{l}-0.064 \\
(1.01)\end{array}$ & $\begin{array}{l}-0.201 * * \\
(2.49)\end{array}$ \\
\hline toe*relatroa & $\begin{array}{l}0.010 \\
(0.23)\end{array}$ & $\begin{array}{l}0.027 \\
(0.41)\end{array}$ & $\begin{array}{l}0.015 \\
(0.34)\end{array}$ & $\begin{array}{l}0.042 \\
(0.60)\end{array}$ \\
\hline relsize & & $\begin{array}{l}0.062 \\
(0.77)\end{array}$ & & $\begin{array}{l}0.063 \\
(1.06)\end{array}$ \\
\hline toe & & $\begin{array}{l}-0.073 \\
(0.67)\end{array}$ & & $\begin{array}{l}-0.051 \\
(0.52)\end{array}$ \\
\hline $\mathrm{cb}$ & & $\begin{array}{l}-0.153^{*} \\
(1.92)\end{array}$ & & $\begin{array}{l}-0.093 \\
(1.54)\end{array}$ \\
\hline regul_strength & & $\begin{array}{l}0.010 \\
(0.29)\end{array}$ & & $\begin{array}{l}0.069^{* *} \\
(2.07)\end{array}$ \\
\hline di & & $\begin{array}{l}-0.126 \\
(0.97)\end{array}$ & & $\begin{array}{l}-0.024 \\
(0.21)\end{array}$ \\
\hline $\mathrm{cb}^{*}$ regul & & $\begin{array}{l}0.081 * * \\
(2.04)\end{array}$ & & $\begin{array}{l}0.077 * * \\
(2.16)\end{array}$ \\
\hline $\mathrm{cb}^{*} \mathrm{di}$ & & $\begin{array}{l}0.295^{* *} \\
(2.38)\end{array}$ & & $\begin{array}{l}0.326^{* *} \\
(2.49)\end{array}$ \\
\hline hhi & & $\begin{array}{l}0.196 \\
(0.42)\end{array}$ & & $\begin{array}{l}-1.689^{*} \\
(1.91)\end{array}$ \\
\hline gdpgrwth & $\begin{array}{l}0.028 \\
(0.99)\end{array}$ & $\begin{array}{l}0.026 \\
(0.84)\end{array}$ & $\begin{array}{l}0.025 \\
(1.35)\end{array}$ & $\begin{array}{l}0.020 \\
(0.73)\end{array}$ \\
\hline Constant & $\begin{array}{l}0.220 * * * \\
(2.64)\end{array}$ & $\begin{array}{l}0.373 \\
(1.08)\end{array}$ & $\begin{array}{l}-0.160 * * * \\
(3.13)\end{array}$ & $\begin{array}{l}-0.394 \\
(1.49)\end{array}$ \\
\hline Observations & 102 & 90 & 102 & 90 \\
\hline Adj. R-squared & 0.264 & 0.297 & 0.419 & 0.444 \\
\hline F-Stat & 8.25 & 4.37 & 16.61 & 14.85 \\
\hline
\end{tabular}

The dependent variable are merger-related changes in acquirer return on equity from -1 to +2 years relative to the merger completion year. The prefix relat denotes similarities between acquirer and target measured as acquirer values minus target values in one fiscal year before the acquisition. Bank controls refer to the acquiring bank. Capasset is the equity to assets ratio, t1rwa is the tier 1 capital to risk-weighted assets ratio and totalrwa is total regulatory capital to risk-weighted assets, liquid are liquid assets over customer and short-term deposits. Roa is return on assets and interest is net interest income over total operating income. Country controls refer to the acquirer country in the year of the acquisition completion. regul_stregnth is the an index of regulatory strength, di an index of deposit insurance regime, gdpgwrth is real GDP growth, cb is a dummy which is one if the deal is a cross-border deal (and zero otherwise), relsize are target assets divided by acquiring bank assets and toe is a binary variable which is one if the acquirer owns some equity in the target before the focal acquisition (and zero otherwise).Robust t statistics in parentheses.

* significant at $10 \% ; *$ significant at $5 \% ; * * *$ significant at $1 \%$ 
Table 7 Regressions on Merger-related changes in Acquirer Liquidity

\begin{tabular}{|c|c|c|c|c|}
\hline & \multicolumn{2}{|c|}{ Absolute Values } & \multicolumn{2}{|c|}{ Industry-adjusted Values } \\
\hline & (1) & $(2)$ & (3) & $(4)$ \\
\hline \multirow[t]{2}{*}{ liquid $_{t-1}$} & $-1.290 * * *$ & $-1.221 * * *$ & $-0.625 * * *$ & $-0.831 * * *$ \\
\hline & $(3.70)$ & $(3.63)$ & $(3.43)$ & $(3.35)$ \\
\hline \multirow[t]{2}{*}{ relatliquid } & -0.929 & -1.009 & -0.877 & -1.072 \\
\hline & $(1.40)$ & $(1.64)$ & $(1.24)$ & $(1.62)$ \\
\hline \multirow[t]{2}{*}{ toe*relatliquid } & $0.281 * * *$ & $0.368 * * *$ & 0.122 & $0.307 * *$ \\
\hline & $(2.71)$ & $(3.03)$ & $(1.20)$ & $(2.58)$ \\
\hline \multirow[t]{2}{*}{ relsize } & & -3.278 & & -1.038 \\
\hline & & $(0.92)$ & & $(0.23)$ \\
\hline \multirow[t]{2}{*}{ toe } & & -0.680 & & -0.608 \\
\hline & & $(0.06)$ & & $(0.05)$ \\
\hline \multirow[t]{2}{*}{$\mathrm{cb}$} & & 4.613 & & 9.313 \\
\hline & & $(0.65)$ & & $(1.12)$ \\
\hline \multirow[t]{2}{*}{ regul_strength } & & $-5.199 * *$ & & -3.066 \\
\hline & & $(2.03)$ & & $(1.46)$ \\
\hline \multirow[t]{2}{*}{ di } & & -5.137 & & 9.162 \\
\hline & & $(0.56)$ & & $(0.99)$ \\
\hline \multirow[t]{2}{*}{$\mathrm{cb}^{*}$ regul } & & $7.605^{*}$ & & 6.120 \\
\hline & & $(1.85)$ & & $(1.44)$ \\
\hline \multirow[t]{2}{*}{$\mathrm{cb}^{*} \mathrm{di}$} & & $21.632 *$ & & 15.644 \\
\hline & & $(1.68)$ & & $(1.16)$ \\
\hline \multirow[t]{2}{*}{ hhi } & & -46.087 & & 15.216 \\
\hline & & $(1.02)$ & & $(0.27)$ \\
\hline \multirow[t]{2}{*}{ gdpgrwth } & 2.182 & $2.868^{*}$ & 0.326 & 1.862 \\
\hline & $(1.58)$ & $(1.80)$ & $(0.35)$ & $(1.10)$ \\
\hline \multirow[t]{2}{*}{ Constant } & $25.873 * * *$ & $60.521 * *$ & -0.531 & -4.302 \\
\hline & (2.69) & $(2.24)$ & $(0.13)$ & $(0.21)$ \\
\hline Observations & 92 & 80 & 92 & 80 \\
\hline Adj. R-squared & 0.245 & 0.275 & 0.092 & 0.188 \\
\hline F-Stat & 3.58 & 1.54 & 3.16 & 1.45 \\
\hline
\end{tabular}

The dependent variable are merger-related changes in acquirer liquid assets to customer and short-tern funding from -1 to +2 years relative to the merger completion year. The prefix relat denotes similarities between acquirer and target measured as acquirer values minus target values in one fiscal year before the acquisition. Bank controls refer to the acquiring bank. Capasset is the equity to assets ratio, t1rwa is the tier 1 capital to riskweighted assets ratio and totalrwa is total regulatory capital to risk-weighted assets, liquid are liquid assets over customer and short-term deposits. Roa is return on assets and interest is net interest income over total operating income. Country controls refer to the acquirer country in the year of the acquisition completion. regul_stregnth is the an index of regulatory strength, di an index of deposit insurance regime, gdpgwrth is real GDP growth, cb is a dummy which is one if the deal is a cross-border deal (and zero otherwise), relsize are target assets divided by acquiring bank assets and toe is a binary variable which is one if the acquirer owns some equity in the target before the focal acquisition (and zero otherwise).Robust $t$ statistics in parentheses.

* significant at $10 \%$; * significant at 5\%; *** significant at $1 \%$ 
Table 8 Regressions on Merger-related changes in Target Capitalization

\begin{tabular}{|c|c|c|c|c|}
\hline & \multicolumn{2}{|c|}{ Absolute Values } & \multicolumn{2}{|c|}{ Industry-adjusted Values } \\
\hline & (1) & (3) & (4) & (6) \\
\hline \multirow[t]{2}{*}{ capasset $_{\mathrm{t}-1}$} & -0.535 & -0.294 & -0.311 & -0.407 \\
\hline & $(1.35)$ & $(0.77)$ & $(1.07)$ & $(1.04)$ \\
\hline \multirow[t]{2}{*}{ relatlever } & -0.329 & -0.019 & -0.122 & -0.099 \\
\hline & $(0.90)$ & $(0.06)$ & $(0.55)$ & $(0.33)$ \\
\hline \multirow[t]{2}{*}{ toe $*$ relatlever } & 0.227 & -0.087 & 0.027 & -0.128 \\
\hline & $(1.26)$ & $(0.31)$ & $(0.13)$ & $(0.43)$ \\
\hline \multirow[t]{2}{*}{ relsize } & & -0.535 & & -0.563 \\
\hline & & $(1.26)$ & & $(1.47)$ \\
\hline \multirow[t]{2}{*}{ toe } & & -4.205 & & -4.328 \\
\hline & & $(1.27)$ & & $(1.48)$ \\
\hline \multirow[t]{2}{*}{$\mathrm{cb}$} & & -1.203 & & -0.556 \\
\hline & & $(0.70)$ & & $(0.35)$ \\
\hline \multirow[t]{2}{*}{ regul_strength } & & 0.068 & & 0.445 \\
\hline & & $(0.13)$ & & $(0.70)$ \\
\hline \multirow[t]{2}{*}{ di } & & $5.448 *$ & & 6.641 \\
\hline & & $(1.70)$ & & $(1.58)$ \\
\hline \multirow[t]{2}{*}{ cb*regul } & & 0.115 & & 0.427 \\
\hline & & $(0.18)$ & & $(0.66)$ \\
\hline \multirow[t]{2}{*}{$\mathrm{cb}^{*} \mathrm{di}$} & & 2.679 & & 3.299 \\
\hline & & $(1.15)$ & & $(1.27)$ \\
\hline \multirow[t]{2}{*}{ hhi } & & -6.687 & & -9.678 \\
\hline & & $(0.67)$ & & (1.07) \\
\hline \multirow[t]{2}{*}{ gdpgrwth } & -0.170 & 0.525 & -0.149 & 0.670 \\
\hline & $(0.46)$ & $(0.70)$ & $(0.38)$ & $(0.89)$ \\
\hline \multirow[t]{2}{*}{ Constant } & $4.973 *$ & -3.308 & 0.860 & -10.190 \\
\hline & (1.67) & $(0.77)$ & $(0.50)$ & $(1.25)$ \\
\hline Observations & 84 & 74 & 84 & 74 \\
\hline Adj. R-squared & 0.008 & 0.012 & -0.021 & 0.002 \\
\hline F-Stat & 1.51 & 1.37 & 1.48 & 1.02 \\
\hline
\end{tabular}

The dependent variable is merger-related change in target equity to total assets ratio from -1 to +2 years relative to the merger completion year. The prefix relat denotes similarities between acquirer and target measured as acquirer values minus target values in one fiscal year before the acquisition. Bank controls refer to the acquiring bank. Capasset is the equity to assets ratio, t1rwa is the tier 1 capital to riskweighted assets ratio and totalrwa is total regulatory capital to risk-weighted assets, liquid are liquid assets over customer and short-term deposits. Roa is return on assets and interest is net interest income over total operating income. Country controls refer to the target country in the year of the acquisition completion. regul_stregnth is the an index of regulatory strength, di an index of deposit insurance regime, gdpgwrth is real GDP growth, cb is a dummy which is one if the deal is a cross-border deal (and zero otherwise), relsize are target assets divided by acquiring bank assets and toe is a binary variable which is one if the acquirer owns some equity in the target before the focal acquisition (and zero otherwise).Robust $\mathrm{t}$ statistics in parentheses. ${ }^{*}$ significant at $10 \% ; * *$ significant at $5 \% ; * * *$ significant at $1 \%$ 
Table 9 Regressions on Merger-related changes in Target Performance

\begin{tabular}{|c|c|c|c|c|}
\hline & \multicolumn{2}{|c|}{ Absolute Values } & \multicolumn{2}{|c|}{ Industry-adjusted Values } \\
\hline & (1) & $(2)$ & (3) & (4) \\
\hline \multirow[t]{2}{*}{ roa $_{t-1}$} & -0.272 & -0.173 & -0.303 & -0.119 \\
\hline & $(0.90)$ & $(0.38)$ & $(1.39)$ & $(0.32)$ \\
\hline \multirow[t]{2}{*}{ relatroa } & $0.495^{*}$ & 0.618 & $0.448 * *$ & $0.578^{*}$ \\
\hline & $(1.74)$ & $(1.45)$ & $(2.05)$ & $(1.72)$ \\
\hline \multirow[t]{2}{*}{ toe *relatroa } & -0.000 & 0.046 & -0.190 & -0.090 \\
\hline & $(0.00)$ & $(0.22)$ & $(1.13)$ & $(0.38)$ \\
\hline \multirow[t]{2}{*}{ relsize } & & -0.026 & & -0.013 \\
\hline & & $(0.78)$ & & $(0.39)$ \\
\hline \multirow[t]{2}{*}{ toe } & & -0.182 & & -0.116 \\
\hline & & $(0.64)$ & & $(0.41)$ \\
\hline \multirow[t]{2}{*}{$\mathrm{cb}$} & & -0.054 & & 0.068 \\
\hline & & $(0.19)$ & & $(0.28)$ \\
\hline \multirow[t]{2}{*}{ regul_strength } & & $0.254 * *$ & & $0.235 * *$ \\
\hline & & $(2.28)$ & & $(2.10)$ \\
\hline \multirow[t]{2}{*}{ di } & & 0.653 & & $0.539 *$ \\
\hline & & $(1.62)$ & & $(1.71)$ \\
\hline \multirow[t]{2}{*}{$\mathrm{cb}^{*}$ regul } & & 0.189 & & 0.138 \\
\hline & & $(0.54)$ & & $(0.43)$ \\
\hline \multirow[t]{2}{*}{$\mathrm{cb}^{*} \mathrm{di}$} & & 0.165 & & 0.133 \\
\hline & & $(1.50)$ & & $(1.41)$ \\
\hline \multirow[t]{2}{*}{ hhi } & & $-4.308^{*}$ & & $-5.349 * *$ \\
\hline & & $(1.83)$ & & $(2.56)$ \\
\hline \multirow[t]{2}{*}{ gdpgrwth } & -0.035 & -0.067 & -0.048 & -0.066 \\
\hline & $(0.54)$ & $(0.89)$ & $(0.89)$ & $(1.02)$ \\
\hline \multirow[t]{2}{*}{ Constant } & $0.317 * *$ & -1.475 & 0.169 & $-1.324 *$ \\
\hline & $(2.54)$ & $(1.63)$ & (1.14) & $(1.91)$ \\
\hline Observations & 84 & 74 & 84 & 74 \\
\hline Adj. R- & 0.466 & 0.441 & 0.410 & 0.338 \\
\hline F-Stat & 21.75 & 9.06 & 17.32 & 4.91 \\
\hline
\end{tabular}

The dependent variable is merger-related change in target return on equity from -1 to +2 years relative to the merger completion year. The prefix relat denotes similarities between acquirer and target measured as acquirer values minus target values in one fiscal year before the acquisition. Bank controls refer to the acquiring bank. Capasset is the equity to assets ratio, t1rwa is the tier 1 capital to risk-weighted assets ratio and totalrwa is total regulatory capital to risk-weighted assets, liquid are liquid assets over customer and short-term deposits. Roa is return on assets and interest is net interest income over total operating income. Country controls refer to the target country in the year of the acquisition completion.

regul_stregnth is the an index of regulatory strength, di an index of deposit insurance regime, gdpgwrth is real GDP growth, cb is a dummy which is one if the deal is a cross-border deal (and zero otherwise), relsize are target assets divided by acquiring bank assets and toe is a binary variable which is one if the acquirer owns some equity in the target before the focal acquisition (and zero otherwise).Robust $t$ statistics in parentheses.

* significant at $10 \% ; * *$ significant at $5 \% ; * * *$ significant at $1 \%$ 
Table 10 Regressions on Merger-related changes in Target Liquidity

\begin{tabular}{|c|c|c|c|c|}
\hline & \multicolumn{2}{|c|}{ Absolute Values } & \multicolumn{2}{|c|}{ Industry-adjusted Values } \\
\hline & $(1)$ & (3) & (4) & (6) \\
\hline liquid $_{t-1}$ & $\begin{array}{l}-0.552^{* * * *} \\
(3.62)\end{array}$ & $\begin{array}{l}-0.504 * * \\
(2.49)\end{array}$ & $\begin{array}{l}-0.288^{* *} \\
(2.03)\end{array}$ & $\begin{array}{l}-0.396^{* *} \\
(2.59)\end{array}$ \\
\hline relatliquid & $\begin{array}{l}-0.097 \\
(0.53)\end{array}$ & $\begin{array}{l}-0.011 \\
(0.04)\end{array}$ & $\begin{array}{l}0.043 \\
(0.30)\end{array}$ & $\begin{array}{l}0.032 \\
(0.18)\end{array}$ \\
\hline toe *relatliquid & $\begin{array}{l}0.065 \\
(0.23)\end{array}$ & $\begin{array}{l}-0.074 \\
(0.28)\end{array}$ & $\begin{array}{l}0.191 \\
(0.62)\end{array}$ & $\begin{array}{l}0.036 \\
(0.12)\end{array}$ \\
\hline relsize & & $\begin{array}{l}0.500 \\
(0.36)\end{array}$ & & $\begin{array}{l}1.790 \\
(1.42)\end{array}$ \\
\hline toe & & $\begin{array}{l}-11.932 * \\
(1.78)\end{array}$ & & $\begin{array}{l}-11.266 \\
(1.39)\end{array}$ \\
\hline $\mathrm{cb}$ & & $\begin{array}{l}-5.606 \\
(0.93)\end{array}$ & & $\begin{array}{l}-8.650 \\
(1.48)\end{array}$ \\
\hline regul_strength & & $\begin{array}{l}-0.977 \\
(0.33)\end{array}$ & & $\begin{array}{l}-0.613 \\
(0.19)\end{array}$ \\
\hline di & & $\begin{array}{l}18.003 \\
(1.52)\end{array}$ & & $\begin{array}{l}20.374^{*} \\
(1.83)\end{array}$ \\
\hline $\mathrm{cb}^{*}$ regul & & $\begin{array}{l}-0.299 \\
(0.12)\end{array}$ & & $\begin{array}{l}0.636 \\
(0.23)\end{array}$ \\
\hline $\mathrm{cb}^{*} \mathrm{di}$ & & $\begin{array}{l}14.461 \\
(1.58)\end{array}$ & & $\begin{array}{l}19.926 * * \\
(2.18)\end{array}$ \\
\hline hhi & & $\begin{array}{l}42.557 \\
(0.55)\end{array}$ & & $\begin{array}{l}62.284 \\
(0.72)\end{array}$ \\
\hline gdpgrwth & $\begin{array}{l}-0.065 \\
(0.05)\end{array}$ & $\begin{array}{l}1.904 \\
(1.20)\end{array}$ & $\begin{array}{l}-0.695 \\
(0.46)\end{array}$ & $\begin{array}{l}1.015 \\
(0.55)\end{array}$ \\
\hline Constant & $\begin{array}{l}12.318 \\
(1.63)\end{array}$ & $\begin{array}{l}-13.102 \\
(0.48)\end{array}$ & $\begin{array}{l}2.453 \\
(0.39)\end{array}$ & $\begin{array}{l}-28.494 \\
(1.19)\end{array}$ \\
\hline Observations & 73 & 63 & 73 & 63 \\
\hline Adj. R-squared & 0.119 & 0.145 & 0.067 & 0.087 \\
\hline F-Stat & 4.28 & 4.95 & 2.70 & 5.11 \\
\hline
\end{tabular}

The dependent variable is merger-related change in target liquid assets to customer and short-tern funding from -1 to +2 years relative to the merger completion year. The prefix relat denotes similarities between acquirer and target measured as acquirer values minus target values in one fiscal year before the acquisition. Bank controls refer to the acquiring bank. Capasset is the equity to assets ratio, tlrwa is the tier 1 capital to risk-weighted assets ratio and totalrwa is total regulatory capital to risk-weighted assets, liquid are liquid assets over customer and short-term deposits. Roa is return on assets and interest is net interest income over total operating income. Country controls refer to the target country in the year of the acquisition completion. regul stregnth is the an index of regulatory strength, di an index of deposit insurance regime, gdpgwrth is real GDP growth, cb is a dummy which is one if the deal is a cross-border deal (and zero otherwise), relsize are target assets divided by acquiring bank assets and toe is a binary variable which is one if the acquirer owns some equity in the target before the focal acquisition (and zero otherwise). Robust $t$ statistics in parentheses.

$*$ significant at $10 \% ; * *$ significant at $5 \% ; * * *$ significant at $1 \%$ 